\title{
diDaD - diségno e Didattica a Distanza. Tre esperienze di rimediazione
}

\author{
Paolo Belardi \\ Valeria Menchetelli \\ Giovanna Ramaccini
}

Abstract

È ormai acclarato come all'iniziale stravolgimento legato al passaggio improvviso dalla didattica universitaria tradizionale alla didattica a distanza sia oggi subentrata la consapevolezza delle potenzialità innovative legate all'utilizzo diffuso della modalità telematica. A partire dall'analisi critica di una serie di sondaggi che sono stati volti ad analizzare e interpretare le opinioni di studenti e docenti in merito alla $\mathrm{DaD}$, il presente contributo si concentra sulle ripercussioni delle attività formative online nell'ambito delle discipline del diségno, restituendo uno scenario che ne rivela l'intrinseca attitudine alla rimediazione della distanza. In questo contesto vengono presentati tre casi studio, ideati e sviluppati in piena pandemia nell'ambito dell'offerta formativa del Dipartimento di Ingegneria Civile e Ambientale dell'Università degli Studi di Perugia, che hanno costituito tre distinte occasioni di sperimentazione delle potenzialità della $\mathrm{DaD}$, sottolineandone gli aspetti peculiari che non potranno essere trascurati anche in vista dell'integrazione con metodi didattici più tradizionali attuati in condizioni di normalità.

Didattica a Distanza, diségno, rimediazione, tecnologia, pandemia.
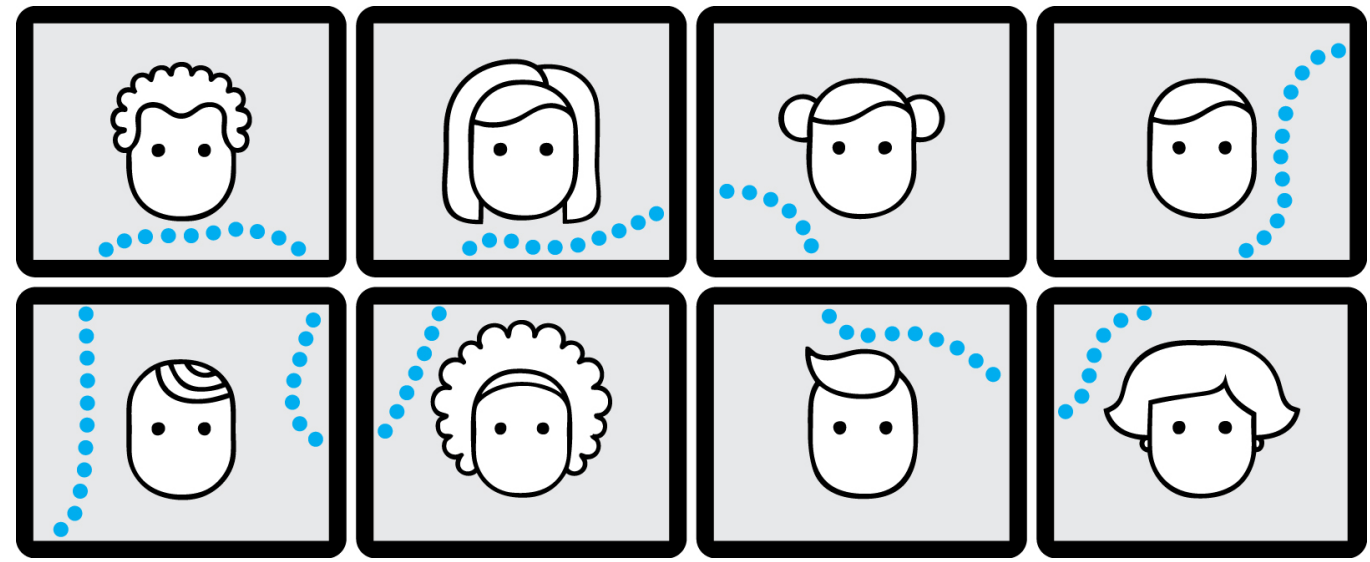


\section{Introduzione: pandemia e $\mathrm{DaD}$}

A un anno di distanza dall'inizio della pandemia da SARS-CoV-2, la didattica universitaria a distanza ha raggiunto una propria, riconoscibile identità. Inizialmente adottata come soluzione per rispondere all'emergenza in corso e "garantire la continuità del servizio" [Draghi, in Tucci 202l], oggi la DaD si pone come modalità di insegnamento stimolante e innovativa, che ha acquisito una evidente autorevolezza. In proposito occorre operare una distinzione tra didattica in emergenza e didattica a distanza propriamente detta [Giralucci 202 I], laddove la prima è una forma di insegnamento/apprendimento fortemente connessa al periodo dell'emergenza sanitaria (e in tal senso inficiata da una maggiore tolleranza verso il mancato raggiungimento di una piena efficacia didattica), mentre la seconda si configura come espressione potenziata della didattica tradizionale adottata in condizioni di normalità dello svolgimento dell'attività formativa [Bruschi, Perissinotto 2020]. Le diverse fasi della pandemia, il cui alternarsi ha determinato la possibilità di sperimentare forme inedite di didattica anche in modalità mista, hanno favorito una progressiva appropriazione dell'utilizzo degli strumenti tecnologici (sia dal lato docente che dal lato studente) e portato all'acquisizione di un maggiore grado di consapevolezza dei limiti, ma anche delle potenzialità, incarnati dalla $\mathrm{DaD}$.

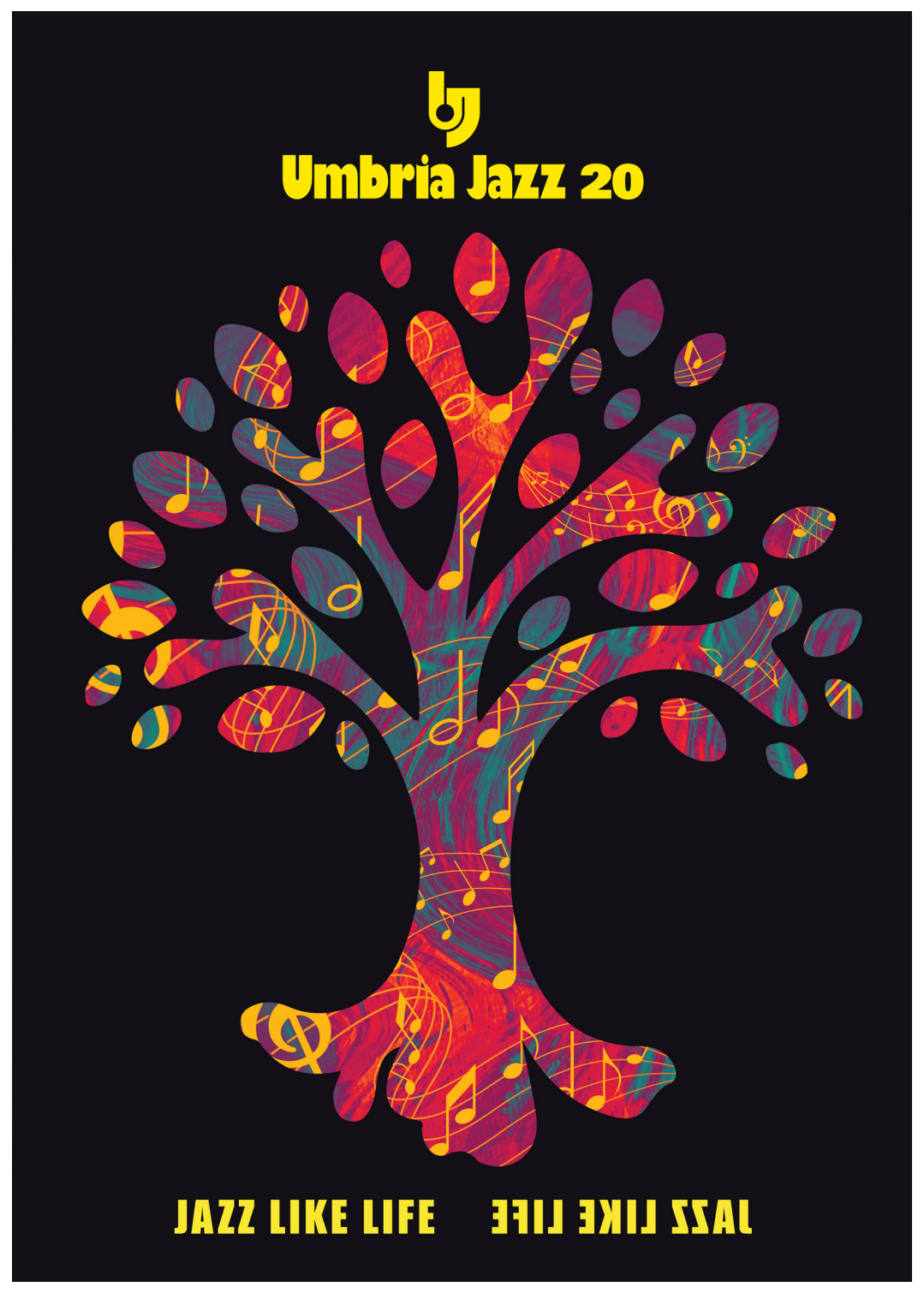




\section{$\mathrm{DaD} / \mathrm{diDaD}$}

Nel contesto universitario, sono stati numerosissimi i sondaggi attivati nel corso della pandemia e volti ad analizzare e interpretare le opinioni di studenti e docenti in merito alla $\mathrm{DaD}$, nell'ottica di giungere a una valutazione delle soluzioni attuate dai diversi Atenei e, potenzialmente, di definire nuovi obiettivi e fissare alcuni standard prestazionali del servizio. I sondaggi, prevalentemente somministrati durante il "semestre Covid- I9" [Ramella, Rostan 2020] hanno avuto modalità di attuazione molto articolate: il bacino di riferimento intervistato era generalmente interno all'Ateneo promotore (corpo dei docenti e/o comunità degli studenti), con l'obiettivo di elaborare modelli di funzionamento efficaci o perfezionare/ottimizzare le procedure già esistenti rispetto all'erogazione della didattica. In tale contesto si collocano, a titolo esemplificativo, le iniziative attivate dalle Università degli Studi dell'Aquila [Proietti 2020], di Firenze [Strambi 2020] e di Catania [Bollettino d'Ateneo 2020], i cui esiti sono generalmente presentati in forma di report sintetico. Tralasciando le iniziative sondaggistiche organizzate a livello dei singoli Dipartimenti o Corsi di Studio [Università degli Studi di Catania 2020; Sapienza Università di Roma 2020], così come quelle proposte da associazioni esterne agli Atenei [Martino 202I; Della Monica 202 I], interessa invece analizzare gli esiti delle attività di rilevazione che hanno coinvolto trasversalmente più atenei, ponendosi come riferimento per il contesto nazionale.Tra queste risalta l'iniziativa condotta dal Centro "Luigi Bobbio" dell'Università di Torino in collaborazione con UNIRES (Italian Centre for Research on Universities \& HE System) che, rivolta alla rete delle Università aderenti, ha dato luogo alla pubblicazione, già nel mese di giugno 2020, di un report analitico [Ramella, Rostan 2020]. Da tale report emerge una complessiva riorganizzazione delle strategie educative adottate nella didattica universitaria, con una riduzione delle attività di tipo collaborativo-innovativo, consentite dall'interazione in modalità tradizionale, a favore dell'aumento delle attività di tipo trasmissivo-dialogico, caratterizzate da una minore interazione tra studente e docente ma potenziate per effetto dell'uso di strumenti informatici. A valle delle iniziative intraprese singolarmente, nel mese di dicembre 2020 ANVUR avvia una propria indagine sui servizi di Didattica a Distanza (DaD) erogati dalle Università [ANVUR 2020], istituendo un gruppo di lavoro dedicato e invitando gli Atenei a partecipare a tre distinte rilevazioni attuate in fasi consequenziali e rivolte rispettivamente alla governance, ai docenti e agli studenti, con l'obiettivo di derivare le strategie da predisporre dopo il superamento della contingenza pandemica. Anche I'Università degli Studi di Perugia partecipa al sondaggio, raccogliendo e sintetizzando i dati acquisiti nelle prime due fasi; l'indagine, tuttora in corso, mostrerà i propri risultati nei mesi a venire. Uno dei temi oggetto di dibattito a proposito di $\mathrm{DaD}$ è l'ipotetico raffronto che vede 'competere' le Università con la rete delle Università telematiche ( $w w w$. ateneionline.it), per le quali l'adozione delle modalità formative online è una scelta fondativa e che risultano in tal senso favorite da una pratica già collaudata anziché adottata come strategia emergenziale [De Paola 2020; Redazione Scuola 202 I].

La DaD è stata sottoposta a screening anche nell'ambito delle discipline del diségno, che si caratterizzano spesso, quando non esclusivamente, per una modalità di erogazione della didattica di tipo laboratoriale e che quindi, almeno nella prima fase dell'emergenza, sono apparse potenzialmente penalizzate dall'obbligo del distanziamento e del ricorso alla formazione per via telematica. Tuttavia, come ben restituito dall'iniziativa \#iorestoinaula \#iodisegnodacasa. Riflessioni sulla didattica del disegno tra comunicazione diretta e mediata (iorestoinaula. unioneitalianadisegno.it), ideata e promossa dalla Commissione formazione dell'Unione Italiana per il Disegno, lo scenario evidenzia un'evoluzione in atto nel settore disciplinare, che si mostra capace di individuare modalità didattiche sperimentali e innovative fortemente orientate alla condivisione della conoscenza e a un complessivo ampliamento della rete dei contatti, che tende a favorire le occasioni di mutuo scambio e di connessione tra saperi. La pandemia da SARS-CoV-2 ha costretto la didattica, compresa quella universitaria, a scontrarsi con una forzata e repentina "rimediazione" delle distanze [Bolter, Grusin 1999;Treleani, Zucconi 2020] così come dei tempi, che ha portato a una trasposizione dell'esperienza "attraverso nuovi dispositivi e in altri contesti" [Pinotti, Somaini 20 I 6, p. I63] e di conseguenza alla "rilocazione" della pratica mediale [Casetti 20 I5]. II diségno esprime una intrinseca at- 
titudine alla rimediazione, ponendosi addirittura ai prodromi della didattica a distanza: basti pensare a come Antonio Manzi vi ricorra per captare l'attenzione degli spettatori delle sue lezioni televisive in Non è mai troppo tardi: "la televisione è fatta di immagini in movimento" e, per ovviare alla natura dello specifico medium, Manzi propone "la soluzione [...] di disegnare: mi bastava schizzare qualcosa, meglio se incomprensibile all'inizio, per cui chi stava a guardare era incuriosito dal disegno che via via prendeva forma e nel frattempo seguiva il mio discorso" [Manzi 2017, p. 53].

Alla luce delle sperimentazioni condotte nell'ambito disciplinare si può allora specializzare la definizione di $\mathrm{DaD}$ mettendo in luce la virtuosa connessione tra diségno e Didattica a Distanza (diDaD) e ricomprendendo all'interno di questa peculiare tipologia di $\mathrm{DaD}$ tutte quelle modalità di insegnamento/apprendimento specifiche messe in atto proprio in virtù dell'identità che connota le discipline del diségno (figura di copertina). In questo contesto, si vogliono analizzare criticamente tre casi studio, ideati e sviluppati in piena pandemia nell'ambito dell'offerta formativa del Dipartimento di Ingegneria Civile e Ambientale dell'Università degli Studi di Perugia, che hanno rappresentato tre distinte occasioni di sperimentazione delle potenzialità offerte dalla Didattica a Distanza.

\section{Tre esperienze di rimediazione}

\section{Umbria Jazz Smart Design}

Tra il 23 marzo e il 18 aprile 2020 si è tenuto il workshop-concorso Umbria Jazz Smart Design, cui hanno partecipato 58 studenti iscritti al Corso di Laurea in Design dell'Università degli Studi di Perugia. II workshop è stato concepito come un vero e proprio concorso a distanza: ideato e diretto da Paolo Belardi insieme a Cristiano Romano, ha avuto come scopo il progetto dell'immagine grafica dell'edizione 2020 del festival musicale internazionale Umbria Jazz. L'obiettivo didattico era quello proprio di un workshop di disegno e comunicazione visiva erogato in modalità tradizionale: formare gli studenti nel progetto grafico, fornendo nozioni di metodologia della progettazione e di composizione dell'artefatto visivo, a partire dall'identificazione del messaggio e del target fino a giungere alla messa in forma efficace delle intenzioni progettuali. Nell'elaborazione delle proprie proposte, gli studenti, coordinati dai docenti Valeria Menchetelli, Paul Henry Robb e Benedetta Terenzi, hanno frequentato lezioni e revisioni interamente online mediante la piattaforma Microsoft Teams, all'interno di un'aula virtuale dedicata, sperimentando modalità didattiche inedite per il progetto grafico. Organizzati in gruppi da due o tre componenti, gli studenti sono giunti all'elaborazione di 27 manifesti originali, nel cui ambito un grand jury internazionale ha selezionato una rosa di 10 proposte destinate a essere utilizzate nella comunicazione delle future edizioni della
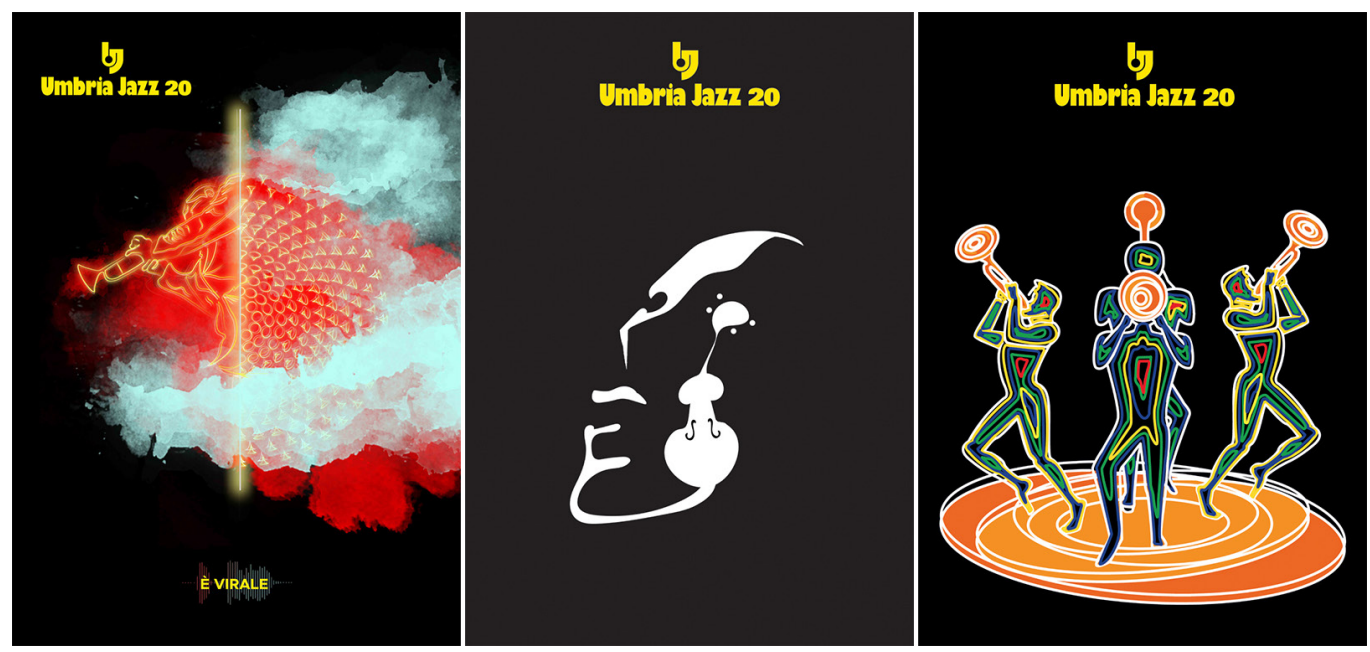
Fig. 3. Umbria Jazz Smart Design, progetti menzionati (da sinistra: Ylenia Bacci, Kristiana Nika; Francesca Melchiorri, Ginevra Moracci: Federica Cencioni, Sofia Fioretti)
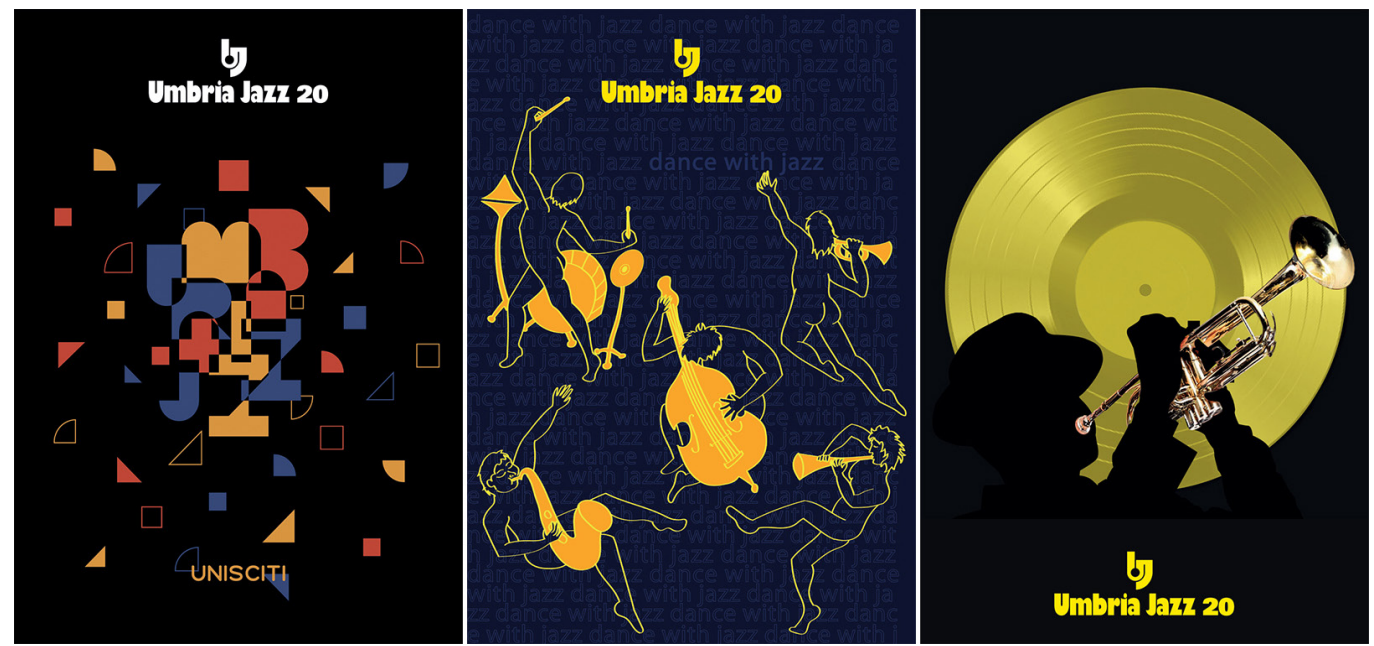

manifestazione; per gli eventi speciali organizzati nel 2020 è stato prescelto il manifesto Life like Jazz (Martina Cinefra, Giuseppe Gullà) (figg. I -4). I manifesti sono stati inoltre presentati in rassegna in un'iniziativa espositiva ospitata presso la sede del Rettorato ( 6 luglio - 30 settembre), nel corso della quale è stato possibile dare un significato corale alle molteplici declinazioni grafiche dei concetti di musica, multiculturalità, empatia, passione che contraddistinguono l'importante festival artistico.
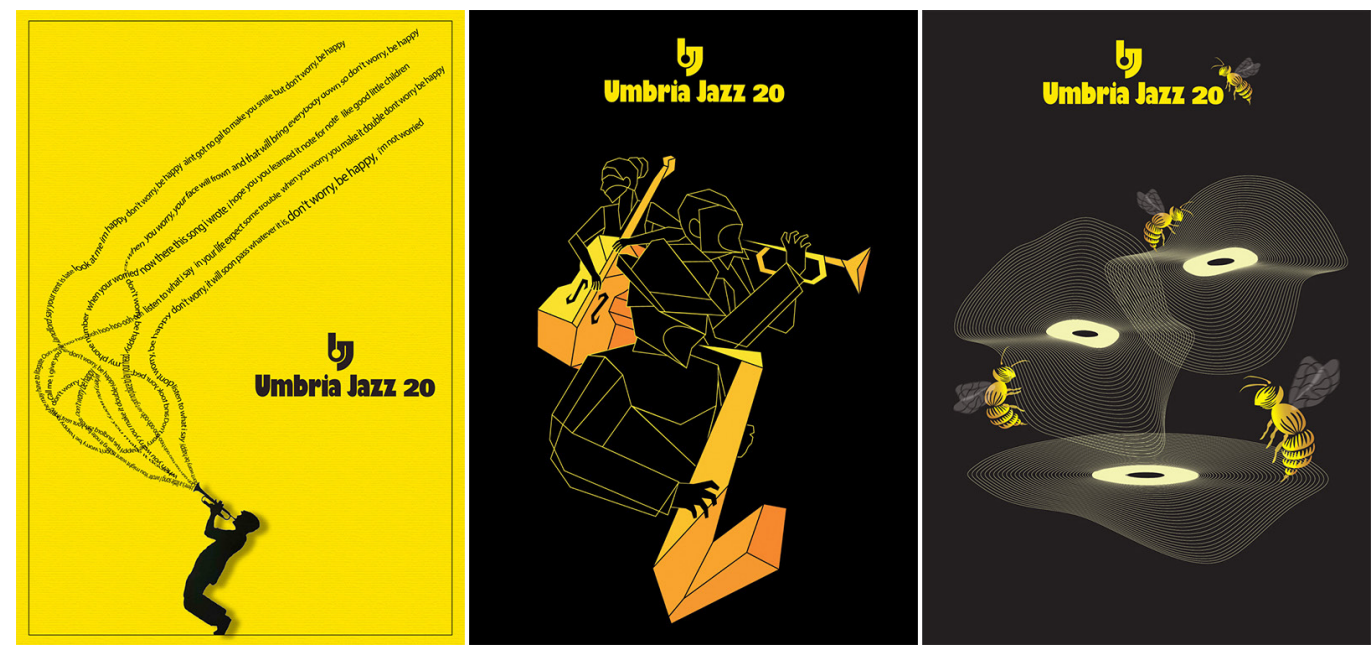

Gesti che non feriscono

Tra il 20 ottobre e il 25 novembre 2020 si è tenuto il workshop di graphic design e comunicazione strategica Gesti che non feriscono, cui hanno partecipato 5 I studenti iscritti al Corso di Laurea in Design dell'Università degli Studi di Perugia. II workshop è stato organizzato sinergicamente dal CUG di Ateneo (Comitato Unico di Garanzia per le pari opportunità, la valorizzazione del benessere di chi lavora e contro le discriminazioni) e dal Corso di Laurea in Design (responsabile scientifico Paolo Belardi) e ha avuto come finalità la progettazione di una campagna comunicativa istituzionale contro la violenza di genere. L'obiettivo formativo è stato quello di fornire agli studenti le competenze necessarie per la progettazione integrale di una campagna di comunicazione, dalla fase di costruzione partecipata del brief a quella di definizione del focus specifico e del target di riferimento, dallo sviluppo del percor- 
Fig. 5. Gesti che non eriscono, progetto vincitore (Filippo Cecchetti)

Fig. 6. Gesti che non feriscono, progetto menzionato Veronica Benicchi, Alessia Sereni).

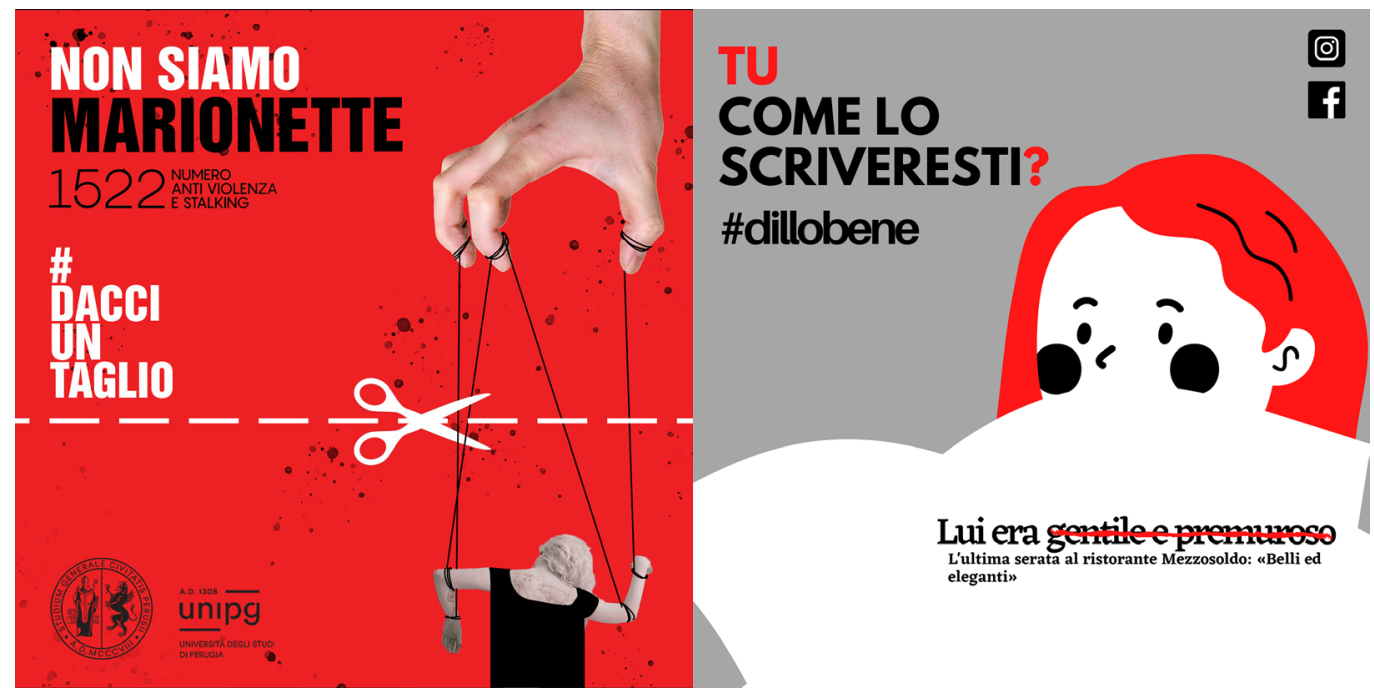

so creativo all'ideazione delle declinazioni multicanale (offline e online), riservando una particolare attenzione al contesto istituzionale di collocazione. Anche in questo caso, le attività didattiche si sono svolte esclusivamente per via telematica tramite Teams: i docenti Giuseppina Bonerba, Valeria Menchetelli, Antonio Picciotti, Paul Henry Robb e Benedetta Terenzi, con la collaborazione di Dino Amenduni, hanno guidato gli studenti nelle diverse fasi del percorso di progettazione. La campagna vincitrice è stata proclamata emblematicamente il 25 novembre 2020 (data in cui si celebra la Giornata internazionale per l'eliminazione della violenza contro le donne) e selezionata da un qualificato panel composto da rappresentanti delle istituzioni, giornalisti, graphic designer, personaggi pubblici e studenti, che ha individuato anche tre progetti menzionati (figg. 5-8). Progettato dallo studente Filippo Cecchetti, il visual \#nonsiamomarionette \#dacciuntaglio invita a compiere il gesto simbolico di 'tagliare' e si rivolge sia alla vittima della violenza, mediante un'esortazione a reagire, sia al carnefice che la attua, mediante l'imperativo di interrompere ogni comportamento di abuso. La fase di attività, programmata per quattro settimane consecutive, è in corso per l'intero mese di febbraio 2021, con una diffusione offline (affissioni in spazi rappresentativi dell'Ateneo) e online (posizionamento social Instagram e Facebook, anche mediante una call to action dedicata).

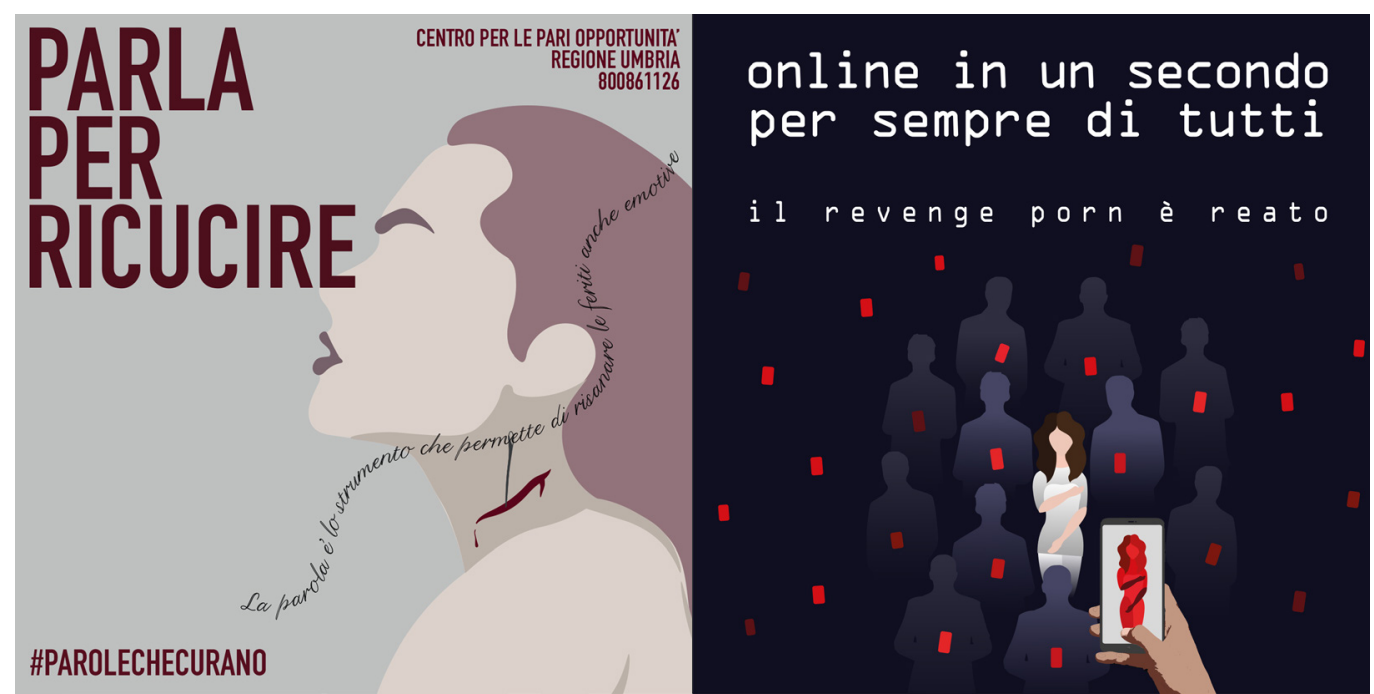

Fig. 7. Gesti che non feriscono, progetto menzionato (Sara Ceccomori, Angelica Ravanelli).

Fig. 8. Gesti che non feriscono, progetto menzionato (Matteo Anderlini, Rita Ester D'Andola). 


\section{Racing}

Tra il 4 e il 18 dicembre 2020 si è tenuto il workshop di graphic design Racing, cui hanno partecipato 4 I studenti iscritti al Corso di Laurea in Design dell'Università degli Studi di Perugia. II workshop è stato ideato e organizzato da Paolo Belardi e ha visto il coinvolgimento di Aldo Drudi, designer di fama internazionale il cui nome è legato alla grafica dei principali piloti di MotoGP, tra cui Valentino Rossi. La finalità principale del workshop ha riguardato il progetto grafico del casco, della livrea e dello scaldacollo destinati a un ipotetico pilota del Team Unipg partecipante al Campionato del Mondo MotoGP e perciò fondato sulla nuova identità visiva dell'Ateneo. Non a caso, al pilota ideale è stato assegnato il numero 12, somma delle cifre che compongono la data 1308, anno di fondazione dello Studium perugino. L'obiettivo formativo è stato quello di fornire agli studenti le competenze necessarie per la progettazione grafica rivolta a un settore in cui gli aspetti comunicativi, legati alla forte riconoscibilità del pilota in pista, si affiancano a vincoli stringenti, legati alle caratteristiche tecniche e di sicurezza dei prodotti. In tal senso, gli studenti sono stati supportati da Pietro Zanetti, responsabile della ditta veneta SPIDI ed esperto di soluzioni tecnologiche per l'abbigliamento utilizzato nel Campionato del Mondo MotoGP. Nell'arco delle due settimane gli studenti (organizzati in gruppi, ciascuno dei quali ha affrontato l'ideazione grafica dedicata a uno dei tre prodotti) sono stati inoltre guidati dalle docentiValeria Menchetelli e Giovanna Ramaccini e dalle tutor Monica Battistoni, Margherita Maria Ristori, Camilla Sorignani. Le attività didattiche si sono svolte per via telematica tramite Teams, con un'unica eccezione: nel rispetto delle norme di contrasto e contenimento dell'emergenza sanitaria, gli studenti hanno avuto la possibilità di osservare e misurare dal vivo alcuni esempi originali di casco, livrea e scaldacollo appositamente fatti recapitare presso il Polo di Ingegneria. II 28 gennaio 202 I, nell'ambito di un evento dedicato, gli esiti del workshop sono stati presentati pubblicamente. Come di rito, un qualificato panel composto da rappresentanti delle istituzioni, giornalisti, graphic designer, personaggi pubblici e studenti ha selezionato le proposte vincitrici per il casco (Sara Aglietti, Marzia Mattioli, Eleonora Tomassini) (fig. 9), per la livrea (Alessandro Moriconi, Elena Tarpani, Alessandro Zambotto) (fig. I0) e per lo scaldacollo (Ciprian Constantin Cazacu, Robert Paolo Requena Contreras, Ehsan Parikhi, Shahrad Shambayati) (fig. I I). Nei prossimi mesi gli studenti saranno coinvolti nella fase di realizzazione, che avrà come esito la messa a punto del completo coordinato destinato al pilota del Club Moto Unipg.

Fig. 9. Racing, casco, progetto vincitore (Sara Aglietti, Marzia Mattioli, Eleonora Tomassini)

Fig. 10. Racing, livrea progetto vincitore (Alessandro Moriconi, Elena Tarpani, Alessandro Zambotto).
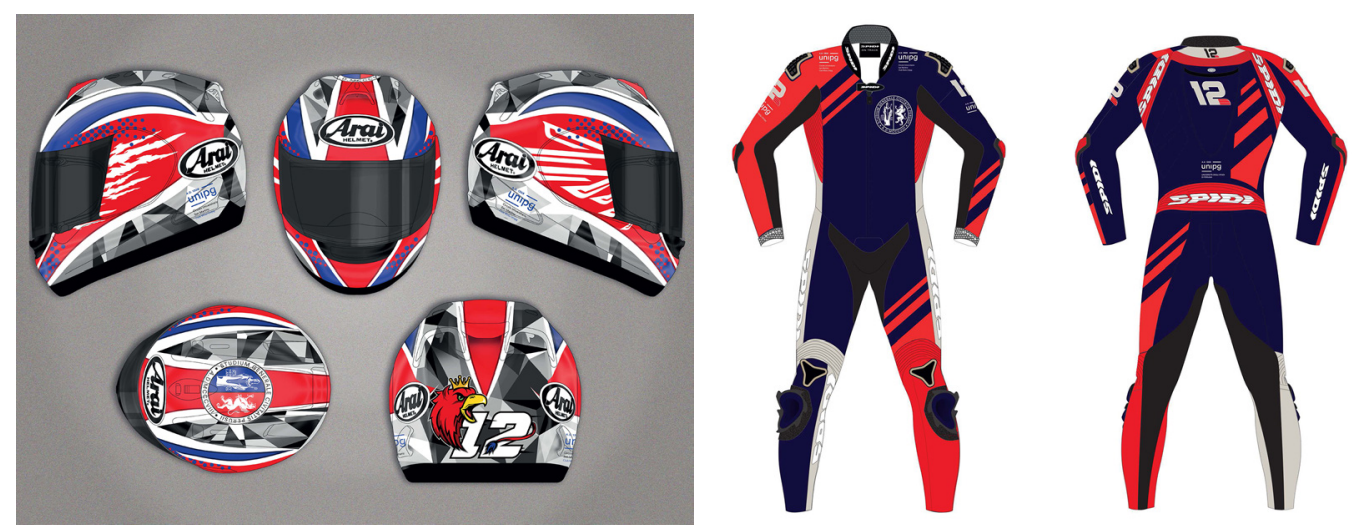

\section{Considerazioni conclusive}

L'impossibilità di svolgere attività laboratoriale convenzionale, che vede studenti e docenti affiancarsi e confrontarsi direttamente e materialmente stratificando segni sul foglio da disegno, nelle tre esperienze presentate è stata compensata dalla maggiore interattività, dall'attenuazione dei filtri interpersonali e dalla più intensa partecipazione collettiva, a favore dell'intero gruppo classe e al di là degli interessi formativi individuali o del gruppo ristretto. L'assiduità di presenza degli studenti e la loro partecipazione attiva agli appun- 
tamenti di lezione e revisione hanno evidenziato una sostanziale efficacia delle modalità didattiche adottate, sebbene il primo workshop sia stato avviato appena a tre settimane dall'inizio del lockdown. In tal senso, gli strumenti messi a disposizione dall'Ateneo e la pronta attivazione della DaD a livello dipartimentale (nel caso del Dipartimento di Ingegneria Civile e Ambientale l'avvio delle lezioni telematiche ha seguito di appena una settimana la sospensione preventiva delle attività didattiche disposta a livello nazionale e di soli tre giorni l'ingresso in lockdown), hanno consentito di svolgere le attività in maniera decisamente efficace. Nel corso dell'evolversi della situazione sanitaria nazionale, dopo il ripristino della possibilità di effettuare spostamenti tra regioni, gli studenti hanno potuto partecipare alla DaD dai luoghi di provenienza, sia in altre Regioni Italiane sia, occasionalmente, all'estero. La partecipazione ampia ha mostrato un'incidenza minima degli effetti del digital divide, con connessioni attivate stabilmente da tutte le sedi. II bilancio positivo delle tre esperienze incoraggia a intraprendere stabilmente un'offerta di diDaD, anche dopo il termine della pandemia, come forma di supporto e integrazione delle modalità tradizionali di erogazione delle attività disciplinari e come ulteriore possibilità di rimediazione, sempre foriera di esperienze innovative.

Fig. II. Racing, scaldacollo, progetto vincitore (Ciprian Constantin Cazacu, Robert Paolo Requena Contreras, Ehsan Parikhi, Shahrad Shambayati).

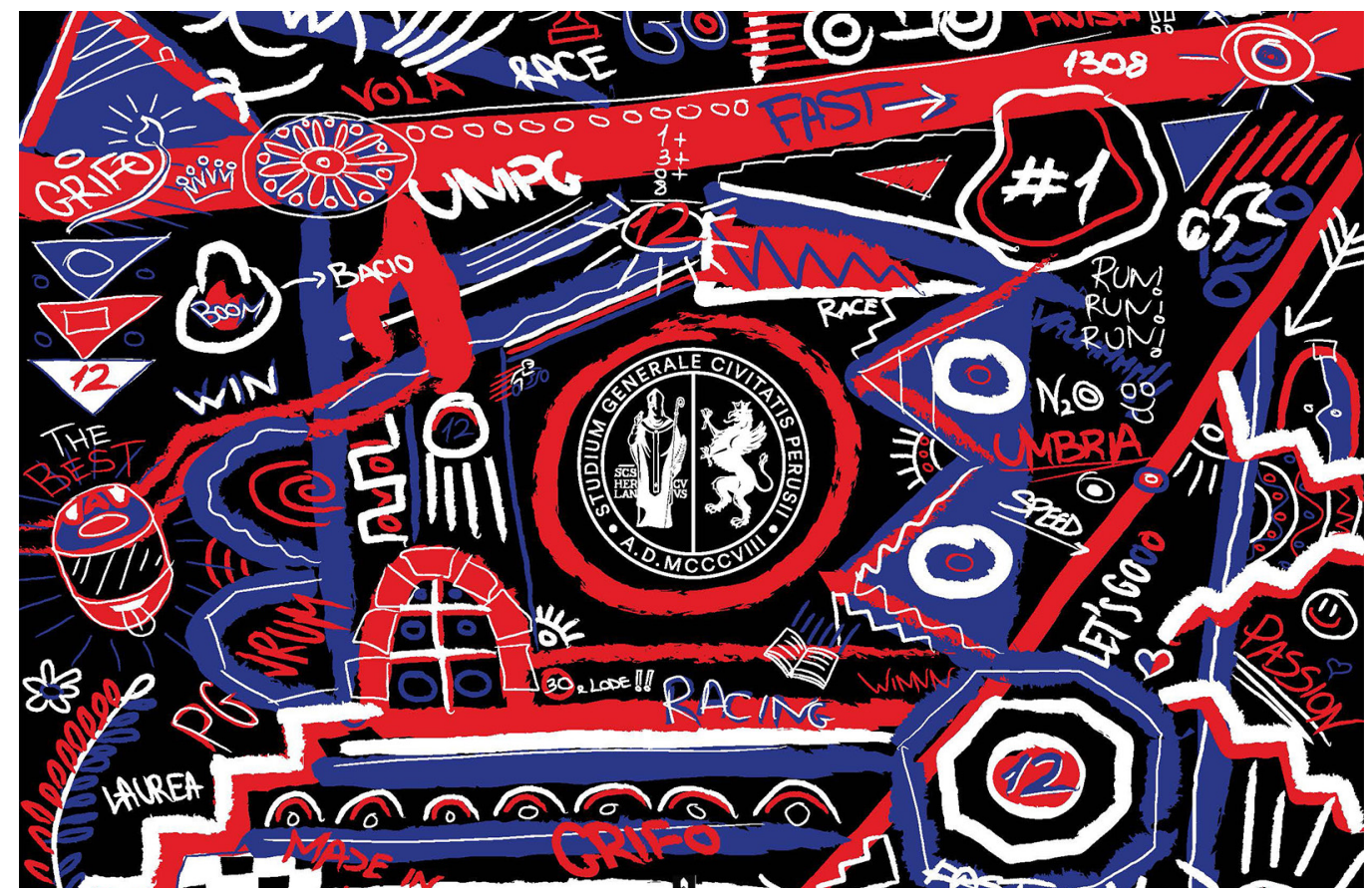

Riferimenti bibliografici

ANVUR (2020). Progetto "Didattica a Distanza - DaD": awviata la rilevazione online <https://www.anvur.it/news/progetto-didattica-a-distanza-dad-avviata-la-rilevazione-online/> (consultato il 23 febbraio 2021).

Bollettino d'Ateneo (28 luglio 2020). Alto gradimento per la Dad di Unict, un sondaggio tra gli studenti premia l'impegno dell'Ateneo durante il lockdown <http://www.bollettino.unict.it/comunicati_stampa/alto-gradimento-la-dad-di-unict-un-sondaggio-tra-gli-studenti-premia-1\%E2\%80\%99impegno> (consultato il 23 febbraio 202I).

Bolter J.-D., Grusin R. (1999). Remediation. Understanding New Media. Cambridge, MA:The MIT Press.

Bruschi B., Perissinotto A. (2020). Didattica a distanza. Com’è, come potrebbe essere. Roma-Bari: Laterza.

Casetti F. (20I5). La galassia Lumière. Sette parole chiave per il cinema che viene. Milano: Saggi Bompiani.

De Paola M. (2020). Così il Covid-1 9 cambia l'università <https://www.lavoce.info/archives/670 I8/cosi-il-covid-I 9-cambia-luniversita/> (consultato il 23 febbraio 2021). 
Della Monica M. P. ( 10 febbraio 202 I). Iniziare l'università ai tempi del Covid-1 9 <https://www.asinupress.com/iniziare-luniversita-ai-tempi-del-covid-19/> (consultato il 23 febbraio 2021).

Giralucci S. (202I). Didattica a distanza. Intervista a Barbara Bruschi <https://fondazionezoe.it/2021/0I/26/intervista-a-barbara-bruschi/> (consultato il 23 febbraio 2021).

Manzi A. (20 I7). Non è mai troppo tardi. Testamento di un maestro. Bologna: EDB, Centro editoriale dehoniano.

Martino S. (202I). Sondaggio Unimore: gli studenti amano la dad <https://www.ilrestodelcarlino.it/reggio-emilia/cronaca/sondaggio-unimore-gli-studenti-amano-la-dad-1.597| 698> (consultato il 23 febbraio 2021).

Pinotti A., Somaini A. (2016). Cultura visuale. Immagini sguardi media dispositivi. Torino: Einaudi.

Proietti G. (2020). Questionario Studenti UnivAQ sulla Didattica a Distanza. Analisi dei Risultati <https://mww.univaq.it/include/ utilities/blob.php?item=file\&table=allegato\&id=4695> (consultato il 23 febbraio 202 I).

Ramella F., Rostan M. (2020). Gli accademici italiani e la didattica a distanza durante l'emergenza Covid-19. Universi-DaD. <https://www.dcps.unito.it/do/documenti.pl/ShowFile?_id=gfk5;field=file;key=4G3PLidHy8YQAwy46cnWQSzYCxRhjocgmo6f2vGxXL03D8js7D6;t=3283> (consultato il 23 febbraio 202I).

Redazione Scuola (202I). Dad e università: i corsi di laurea accessibili da casa raccolti in un portale con le valutazioni di Anvur. <https://scuola24.ilsole24ore.com/art/universita-e-ricerca/202 I-02-03/dad-e-universita-corsi-laurea-accessibili-casa-raccolti-un-portale-le-valutazioni-anvur- 172040.php?uuid=ADil gYHB> (consultato il 23 febbraio 202 I).

Sapienza Università di Roma (2020). Questionario di valutazione dell'esperienza con la didattica a distanza <https://web.uniroma l.it/disp/archivionotizie/questionario-di-valutazione-dellesperienza-con-la-didattica-distanza> (consultato il 23 febbraio 2021 )

Strambi V. (2020). Firenze, il sondaggio: gli studenti universitari preferiscono la didattica a distanza <https://firenze.repubblica.it/ cronaca/2020/09/19/news/firenze_il_sondaggio_gli_studenti_universitari_preferiscono_la_didattica_a_distanza-2678 I 2204/> (consultato il 23 febbraio 202I).

Treleani M., Zucconi F. (2020). Editorial. In Img Journal, 2(3), 6-2 I. <https://doi.org/ I 0.6092/issn.2724-2463/I 2243> (consultato il 23 febbraio 2021 ).

Tucci C. (I 8 febbraio 202 I). L'affondo di Draghi: recuperare le ore perse Verso le prove Invalsi da marzo <https://scuola24.ilsole24ore.com/art/scuola/202 | -02- I 7/I-affondo-draghi-recuperare-ore-perse-le-prove-invalsi-marzo- | 8330 I.php?uuid=ADIR$\mathrm{PbKB}>$ (consultato il 23 febbraio 2021).

Università degli Studi di Catania (2020). Sondaggio per gli studenti sulla Didattica a Distanza <https://www.dfa.unict.it/it/notizie/ sondaggio-gli-studenti-sulla-didattica-distanza> (consultato il 23 febbraio 2021).

\section{Autori}

Paolo Belardi, Università di Perugia, paolo.belardi@unipg.it

Valeria Menchetelli, Università di Perugia, valeria.menchetelli@unipg.it

Giovanna Ramaccini, Università di Perugia, giovanna.ramaccini@unipg.it

Per citare questo capitolo: Belardi Paolo, MenchetelliValeria, Ramaccini Giovanna (2021). diDaD - diségno e Didattica a Distanza. Tre esperienze di rimediazione/diDaD - drawing and Distance Learning. Three remediation experiences. In Arena A., Arena M., Mediati D., Raffa P. (a cura di). Connettere. Un disegno per annodare e tessere. Linguaggi Distanze Tecnologie. Atti del $42^{\circ}$ Convegno Internazionale dei Docenti delle Discipline della Rappresentazione/Connecting. Drawing for weaving relationship. Languages Distances Technologies. Proceedings of the 42th International Conference of Representation Disciplines Teachers. Milano: FrancoAngeli, pp. I334- I35I. 


\title{
diDaD - Drawing and Distance Learning. Three Remediation Experiences
}

\author{
Paolo Belardi \\ Valeria Menchetelli \\ Giovanna Ramaccini
}

\section{Abstract}

It is now clear that the initial confusion linked to the sudden passage from traditional university education to distance education has been replaced by an awareness of the innovative potential linked to the widespread use of telematics. Starting from the critical analysis of a series of polls aimed at analyzing and interpreting the opinions of students and professors regarding Distance Learning, this contribution focuses on the impact of online educational activities in the field of the disciplines of drawing, giving back a scenario that shows their intrinsic attitude towards the remediation of distance. In this framework, three case studies are presented, conceived and developed in full pandemic within the education provided by the Department of Civil and Environmental Engineering of the University of Perugia, which represented three distinct opportunities to test the potential of the DL, highlighting the special aspects that cannot be overlooked even in view of the integration with more traditional education methods applied in normal conditions.

Keywords

Distance Learning, drawing, remediation, technology, pandemic.
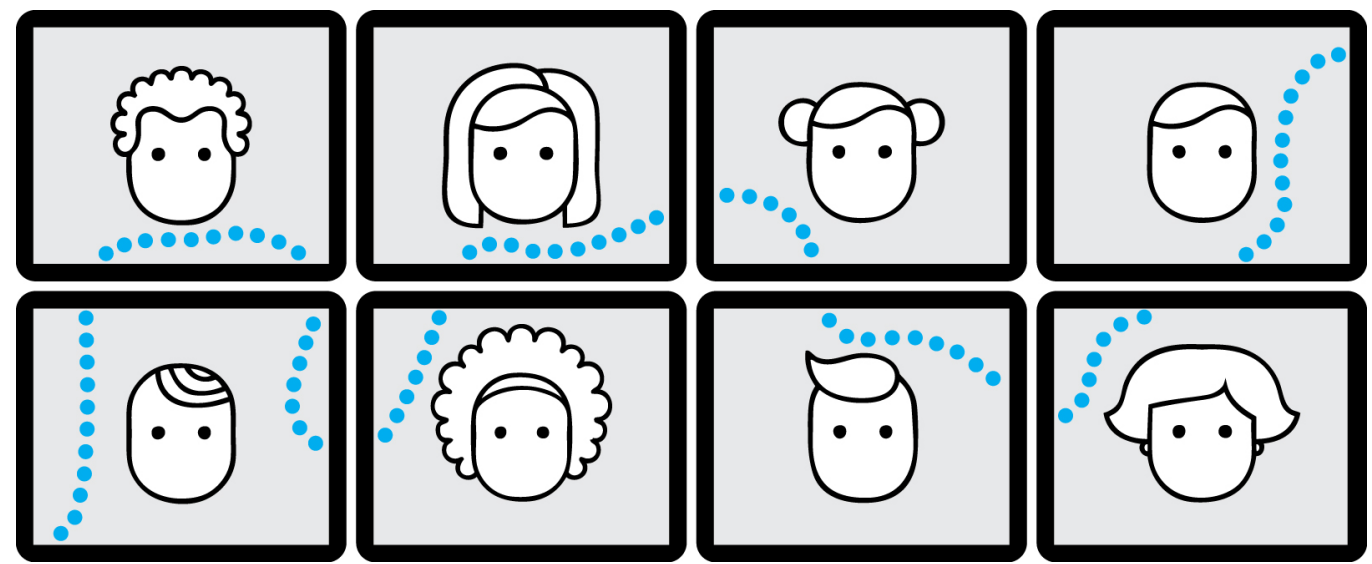


\section{Introduction: pandemic and DL}

One year after the onset of the SARS-CoV-2 pandemic, university Distance Learning has achieved its own, recognizable identity. Initially adopted as a solution to respond to the ongoing emergency and "ensure continuity of service" [Draghi, in Tucci 202 I], today DL stands as a stimulating and innovative teaching modality that has acquired a clear authority. In this regard, it is necessary to make a distinction between emergency learning and distance learning proper [Giralucci 202 I], where the first is a form of teaching/ learning strongly connected to the period of the health emergency (and thus tainted by a greater tolerance for failure to achieve full education effectiveness), while the second is configured as an enhanced expression of traditional learning adopted in normal conditions of educational activities [Bruschi, Perissinotto 2020]. The different phases of the pandemic, the alternation of which has determined the possibility of experimenting with new forms of mixed mode education, have favored a progressive appropriation of the use of technological tools (both on the professor's side and on the student's side) and led to the acquisition of a greater degree of awareness of the limits, but also of the potential, embodied by DL.

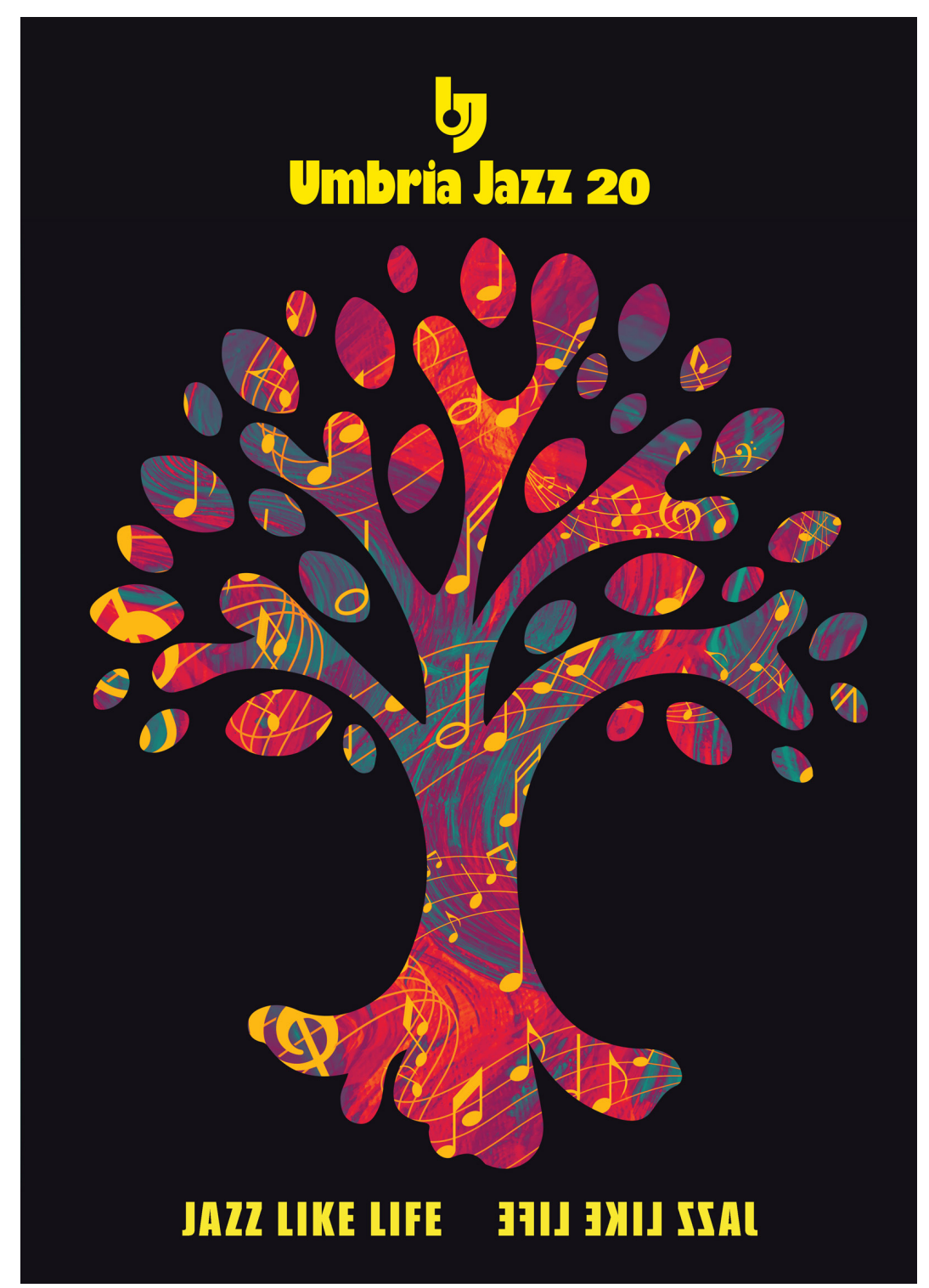




\section{Distance Learning/drawing and Distance Learning}

In the university context, numerous polls were activated during the pandemic and aimed at analyzing and interpreting the opinions of students and professors regarding the $\mathrm{DL}$, with a view to evaluating the solutions implemented by the various universities and, potentially, defining new objectives and setting some service performance standards. The polls, mainly administered during the "Covid- 19 semester" [Ramella, Rostan 2020], had highly articulated implementation methods: the area of reference interviewed was generally internal to the promoting university (professors and/or student community), with the objective of developing effective operating models or perfecting/optimizing existing procedures with respect to the educational provision. In this context there are, for example, the initiatives activated by the Universities of L'Aquila [Proietti 2020], Florence [Strambi 2020] and Catania [Bollettino d'Ateneo 2020], whose results are generally presented in the form of a summary report. Not considering the polling initiatives organized at the level of individual Departments or Courses of Study [Università degli Studi di Catania 2020; Sapienza Università di Roma 2020], as well as those proposed by associations outside the universities [Martino 202 I, Della Monica 202 I], it is interesting instead to analyze the results of survey activities that have involved several universities, acting as a reference point for the national context. Among these, the initiative conducted by the "Luigi Bobbio" Center of the University of Turin in collaboration with UNIRES (Italian Centre for Research on Universities \& HE System) stands out. This initiative, addressed to the network of member universities, resulted in the publication of an analytical report in June 2020 [Ramella, Rostan 2020]. This report shows an overall reorganization of the learning strategies adopted in university education, with a reduction in collaborative-innovative activities, made possible by interaction in traditional modes, in favor of an increase in transmissive-dialogical activities, characterized by less interaction between student and professor but enhanced by the use of computer tools. After the initiatives undertaken individually, in December 2020 ANVUR launches its own survey on Distance Learning (DL) services provided by universities [ANVUR 2020], setting up a dedicated working group and inviting universities to participate in three separate surveys implemented in consequential phases and addressed respectively to governance, professors and students, with the aim of deriving strategies to be set up after the pandemic contingency has passed. Also the University of Perugia participates to the poll, collecting and synthesizing the data acquired in the first two phases; the investigation, still in progress, will show its results in the months to come. One of the issues being debated with regard to $\mathrm{DL}$ is the hypothetical comparison that sees the universities 'competing' with the network of telematic universities ( $w w w$.ateneionline.it), for which the adoption of online learning methods is a fundamental choice and which are therefore favored by a practice that has already been tested rather than adopted as an emergency strategy [De Paola 2020, Redazione Scuola 202 I].

The DL was also screened in the context of the disciplines of drawing, which are often, when not exclusively, characterized by a laboratory-type mode of teaching and which therefore, at least in the first phase of the emergency, appeared to be potentially penalized by the obligation of distancing and the use of computer-based education. However, as the initiative \#iorestoinaula \#iodisegnodacasa. Riflessioni sulla didattica del disegno tra comunicazione diretta e mediata (iorestoinaula.unioneitalianadisegno.it), conceived and promoted by the Education commission of the Unione Italiana per il Disegno shows, the scenario highlights an evolution underway in the disciplinary sector, which shows itself capable of identifying experimental and innovative educational methods strongly oriented to the sharing of knowledge and to an overall widening of the network of contacts, which tends to favour opportunities for mutual exchange and connection between knowledge. The SARS-CoV-2 pandemic has forced learning, including the university one, to contend with a forced and sudden "remediation" of distances [Bolter, Grusin 1999; Treleani, Zucconi 2020] and times, which has led to a transposition of experience "through new devices and into other contexts" [Pinotti, Somaini 20 I6, p. 163] and consequently to the "relocation" of media practice [Casetti 20 I5]. Drawing expresses an intrinsic aptitude for remediation, 
even placing itself at the prodromes of distance learning: just think about how Antonio Manzi uses it to capture the attention of the spectators of his television lessons in Non è mai troppo tardi: "television is made of moving images" and, to obviate the nature of the specific medium, Manzi proposes "the solution [...] to draw: it was enough for me to sketch something, better if incomprehensible at the beginning, so that whoever was watching was intrigued by the drawing that gradually took shape and in the meantime followed my speech" [Manzi, 2017, p. 53].

In the light of the experiments carried out in the disciplinary field, it is possible to specialize the definition of DL by highlighting the virtuous connection between drawing and Distance Learning and including within this particular type of $\mathrm{DL}$ all those specific teaching/learning modalities implemented precisely because of the identity that characterizes the disciplines of drawing. In the light of the experiments carried out in the disciplinary field, it is possible to specialize the definition of DL by highlighting the virtuous connection between drawing and Distance Learning and including within this particular type of DL all those specific teaching/ learning modalities implemented precisely because of the identity that characterizes the disciplines of drawing (fig. 00). In this context, three case studies will be critically analyzed, conceived and developed in the midst of the pandemic within the education provided by the Department of Civil and Environmental Engineering of the University of Perugia, which have represented three distinct opportunities to test the potential offered by Distance Learning.

\section{Three experiences of remediation}

\section{Umbria Jazz Smart Design}

Between 23 March and 18 April 2020 was held the workshop-competition Umbria Jazz Smart Design, which was attended by 58 students enrolled in the Degree Course in Design at the University of Perugia. The workshop was conceived as a real remote competition: conceived and directed by Paolo Belardi together with Cristiano Romano, its aim was to design the graphic image of the 2020 edition of the Umbria Jazz international music festival. The educational objective was that of a workshop of design and visual communication in traditional mode: to train students in graphic design, providing notions of design methodology and composition of the visual artifact, starting from the identification of the message and the target until the effective implementation of design purposes. In the elaboration of their proposals, the students, coordinated by professors Valeria Menchetelli, Paul Henry Robb and Benedetta Terenzi, attended lessons and revisions entirely online by the Microsoft Teams platform, in a dedicated virtual classroom, experimenting with new educational methods for graphic design. Organized in groups of two or three, the students came up with 27 original posters, from which an international grand jury selected a shortlist of 10 proposals to be
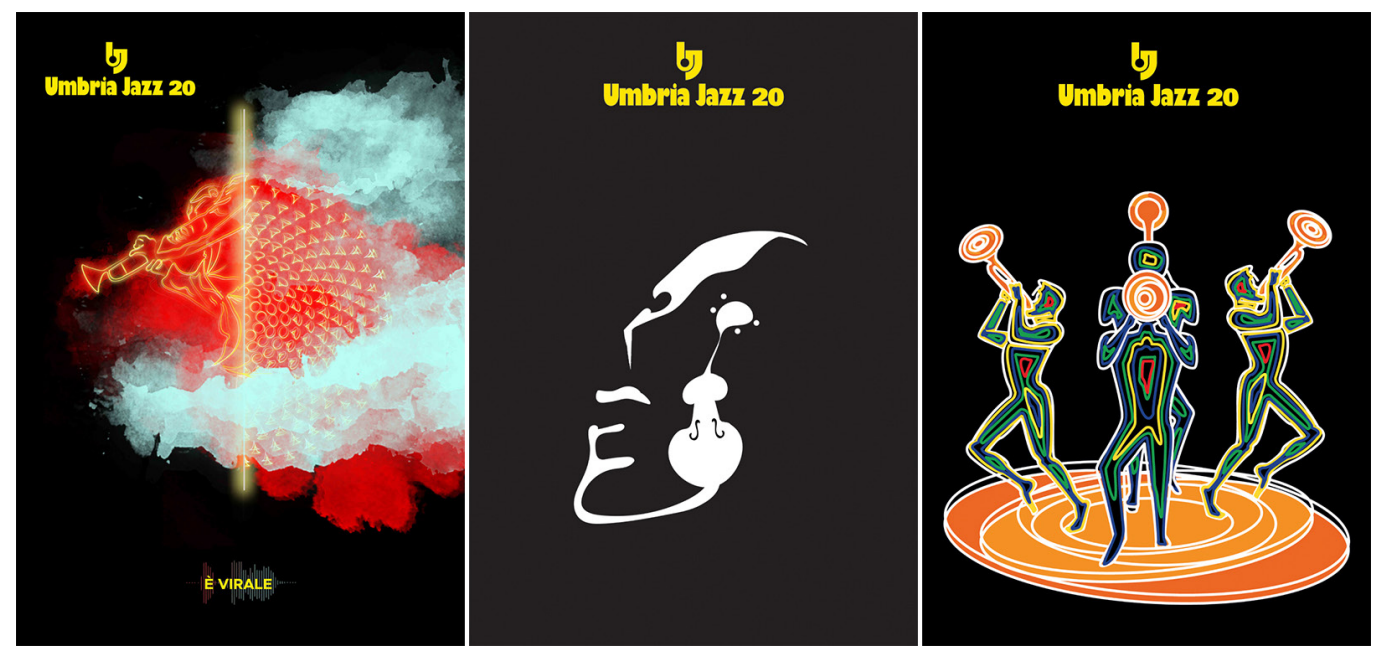
Fig. 3. Umbria Jazz Smart Design, mentioned projects (from left:Ylenia Bacci, Kristiana Nika: Francesca Melchiorri, Ginevra Moracci;

Federica Cencioni, Sofia Fioretti).
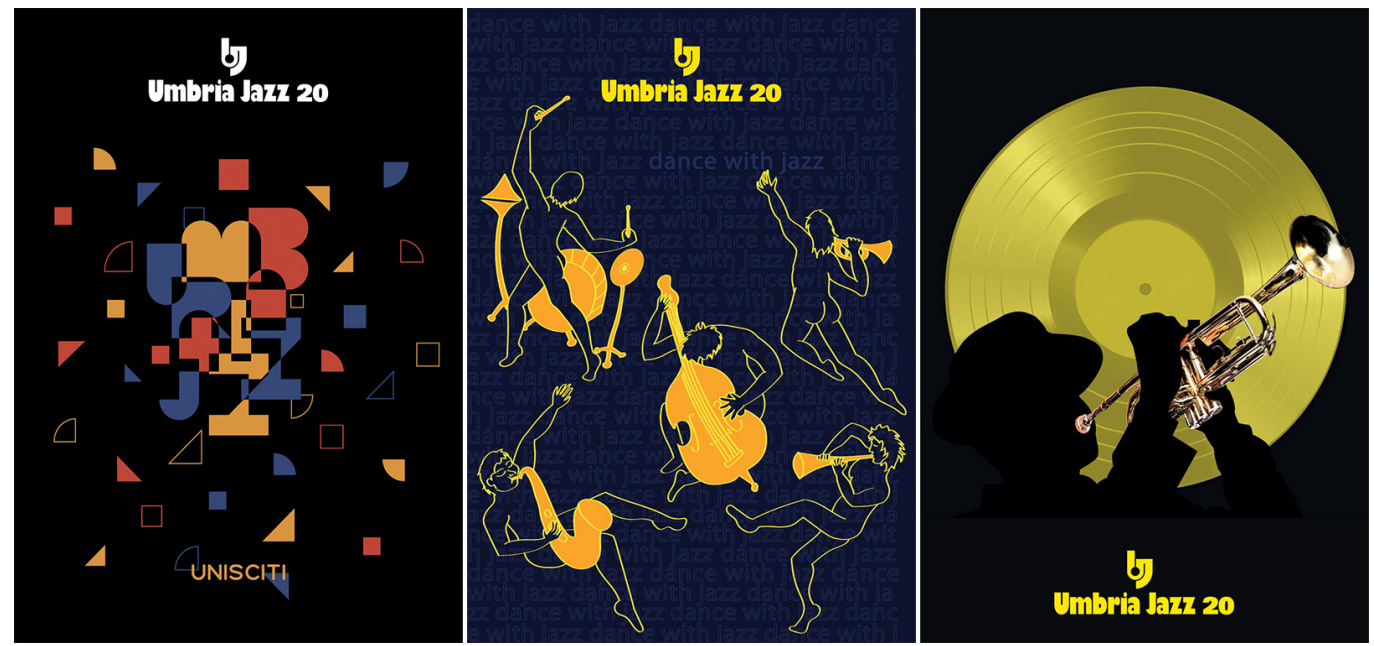

used in the communication of future editions of the event; the poster Life like Jazz was chosen for the special events organized in 2020 (Martina Cinefra, Giuseppe Gullà) (figs. I -4). The posters were also shown in an exhibition hosted at the Rector's headquarters (July 16 - September 30), during which it was possible to give a choral meaning to the many graphic declinations of the concepts of music, multiculturalism, empathy, passion that distinguish the important artistic festival.
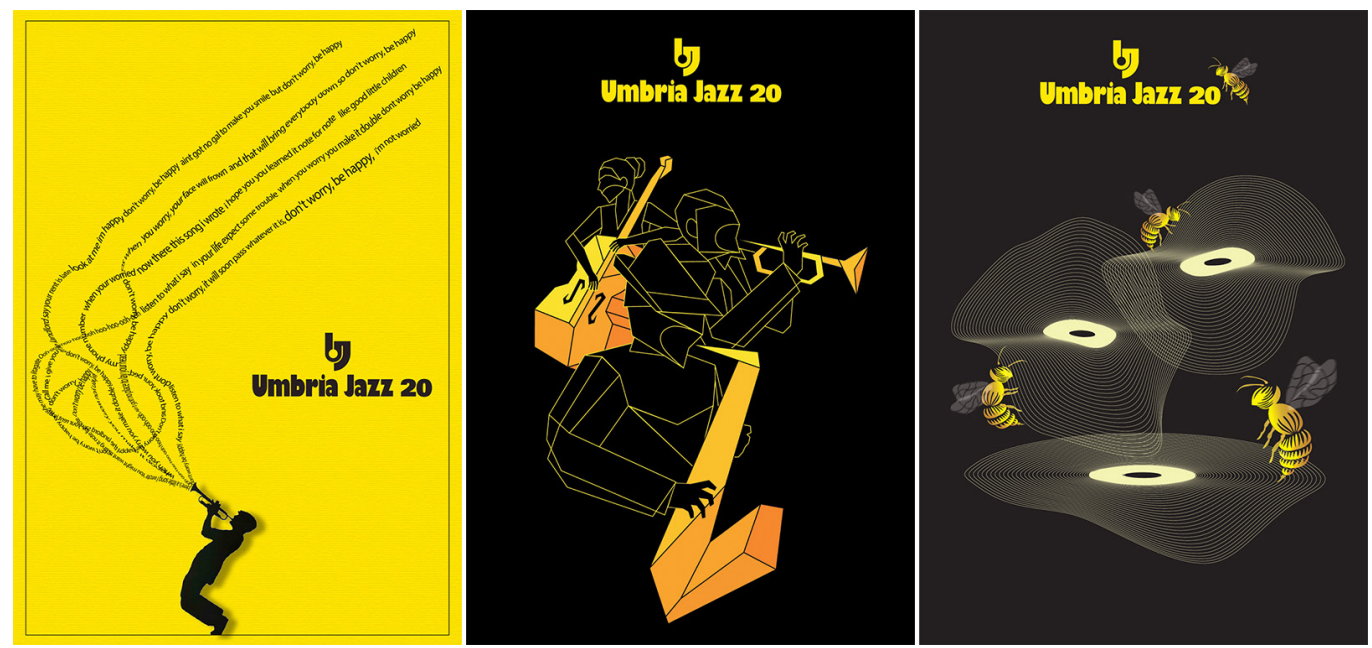

Gesti che non feriscono

Between 20 October and 25 November 2020 the graphic design and strategic communication workshop Gesti che non feriscono (Gestures that don't hurt) was held, with the participation of 5 I students enrolled in the Degree Course in Design at the University of Perugia. The workshop was organized synergistically by the University CUG (Comitato Unico di Garanzia per le pari opportunità, la valorizzazione del benessere di chi lavora e contro le discriminzioni) and the Degree Course in Design (scientific director Paolo Belardi) and was aimed at designing an institutional communication campaign against gender violence. The educational objective was to provide students with the necessary skills for the full design of a communication campaign, from the participatory construction of the brief to the definition of the specific focus and target audience, from the development of the creative path to 
Fig. 5. Gesti che non feriscono, winning project (Filippo Cecchetti).

Fig. 6. Gesti che non feriscono, mentioned Benicchi, Alessia Sereni).

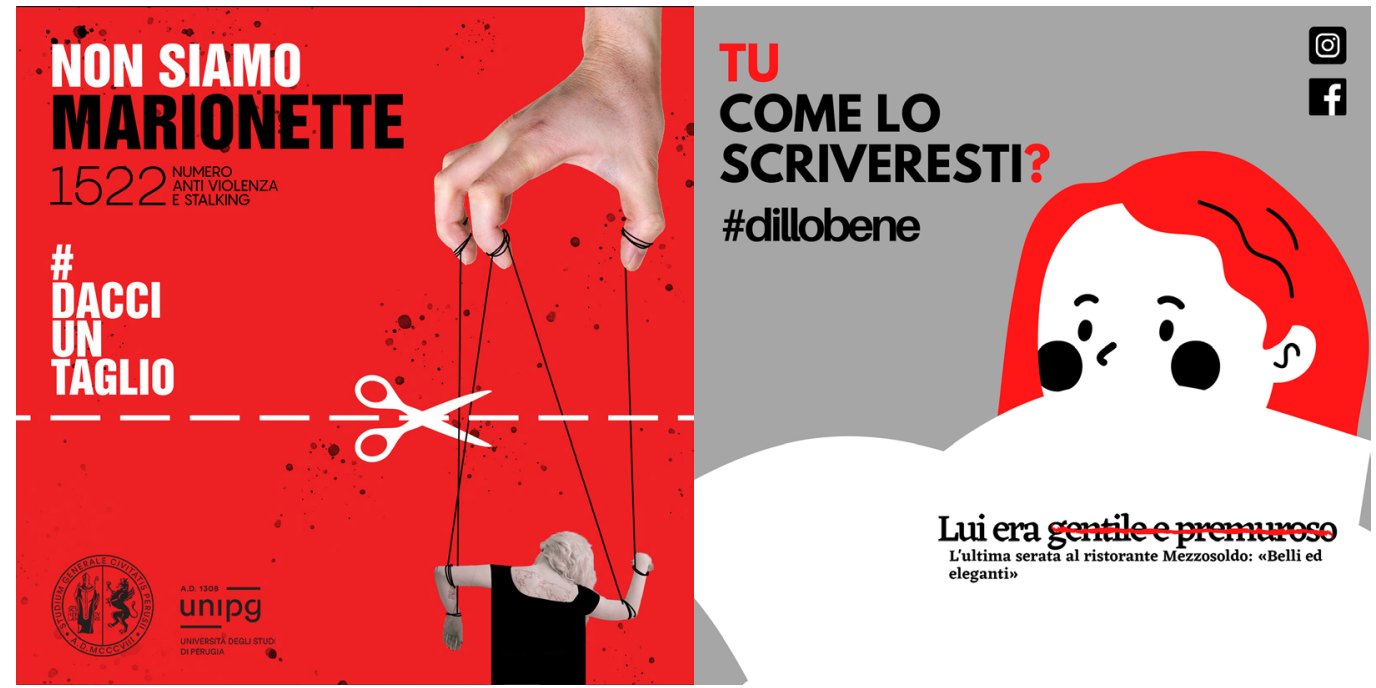

the design of multi-channel declinations (offline and online), paying particular attention to the institutional context of placement. Also in this case, the educational activities were carried out exclusively for telematics by Teams: the professors Giuseppina Bonerba, Valeria Menchetelli, Antonio Picciotti, Paul Henry Robb and Benedetta Terenzi, with the collaboration of Dino Amenduni, guided the students in the different phases of the design process. The winning campaign was emblematically proclaimed on 25 November 2020 (the date on which the International Day for the Elimination of Violence against Women is celebrated) and selected by a qualified panel composed of representatives of institutions, journalists, graphic designers, public figures and students, who also identified three mentioned projects (figs. 5-8). Designed by student Filippo Cecchetti, the visual \#nonsiamomarionette \#dacciuntaglio invites the symbolic gesture of 'cutting' and addresses both the victim of violence, through an exhortation to react, and the perpetrator, through the imperative to stop all abusive behavior. The activity phase, planned for four consecutive weeks, is ongoing for the entire month of February $202 \mathrm{I}$, with an offline (posters in representative spaces of the University) and online (social positioning Instagram and Facebook, including through a dedicated call to action) dissemination.

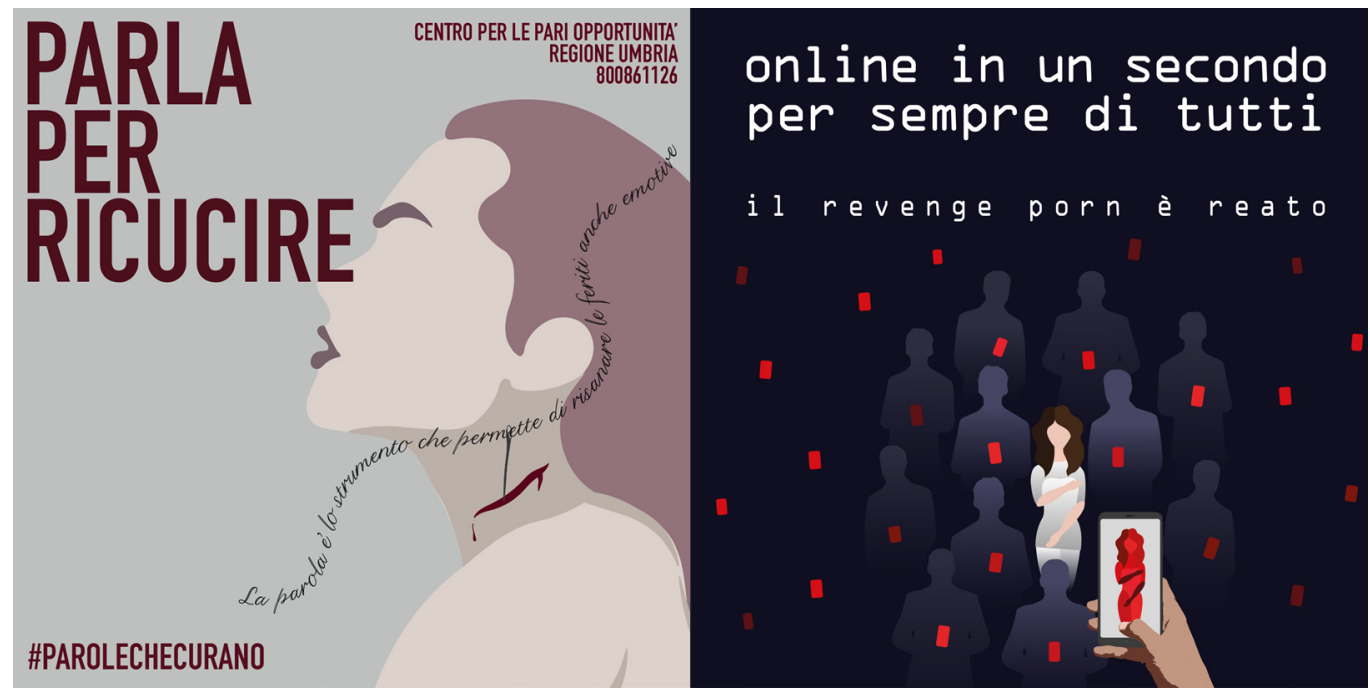
Angelica Ravanelli).

Fig. 8. Gesti che non feriscono, mentioned project (Matteo Anderlini, Rita Ester D'Andola). 


\section{Racing}

Between 4 and 18 December 2020 was held the workshop of graphic design Racing, which was attended by $4 \mathrm{I}$ students enrolled in the Degree Course in Design of the University of Perugia. The workshop was conceived and organized by Paolo Belardi and saw the involvement of Aldo Drudi, internationally renowned designer whose name is linked to the graphics of the main MotoGP riders, including Valentino Rossi.The main purpose of the workshop was the graphic design of the helmet, the livery and the neck warmer for a hypothetical Unipg Team rider participating in the MotoGP World Championship and therefore based on the new visual identity of the University. Not by chance, the ideal pilot has been assigned the number 12, the sum of the digits that make up the date 1308, the year of foundation of the Studium perugino. The educational objective was to provide students with the necessary skills for graphic design aimed at a sector in which the communication aspects, linked to the strong recognition of the pilot on the track, are combined with stringent constraints, related to the technical and safety characteristics of the products. In this sense, the students were supported by Pietro Zanetti, manager of the Venetian company SPIDI and expert in technological solutions for the clothing used in the MotoGP World Championship. During the two weeks, the students (organized in groups, each of which faced the graphic design of one of the three products) were also guided by professors Valeria Menchetelli and Giovanna Ramaccini and tutors Monica Battistoni, Margherita Maria Ristori, Camilla Sorignani. The teaching activities were carried out for telematics by Teams, with one exception: in respect of the rules of contrast and containment of health emergencies, students had the opportunity to observe and measure live some original examples of helmet, livery and neck warmer specially delivered at the Engineering Pole. On 28 January 2021, during a dedicated event, the results of the workshop were publicly presented. As usual, a qualified panel composed of representatives of institutions, journalists, graphic designers, public figures and students has selected the winning proposals for the helmet (Sara Aglietti, Marzia Mattioli, Eleonora Tomassini) (fig. 9), for the livery (Alessandro Moriconi, Elena Tarpani, Alessandro Zambotto) (fig. I0) e for the neck warmer (Ciprian Constantin Cazacu, Robert Paolo Requena Contreras, Ehsan Parikhi, Shahrad Shambayati) (fig. I I). In the coming months the students will be involved in the implementation phase, which will result in the development of the matching set for the pilot of the Club Moto Unipg.

Fig. 9. Racing, helmet, winning project (Sara Aglietti, Marzia Mattioli, Eleonora Tomassini)

Fig. 10. Racing, livery, winning project (Alessandro Moriconi Elena Tarpani,Alessandro Zambotto).
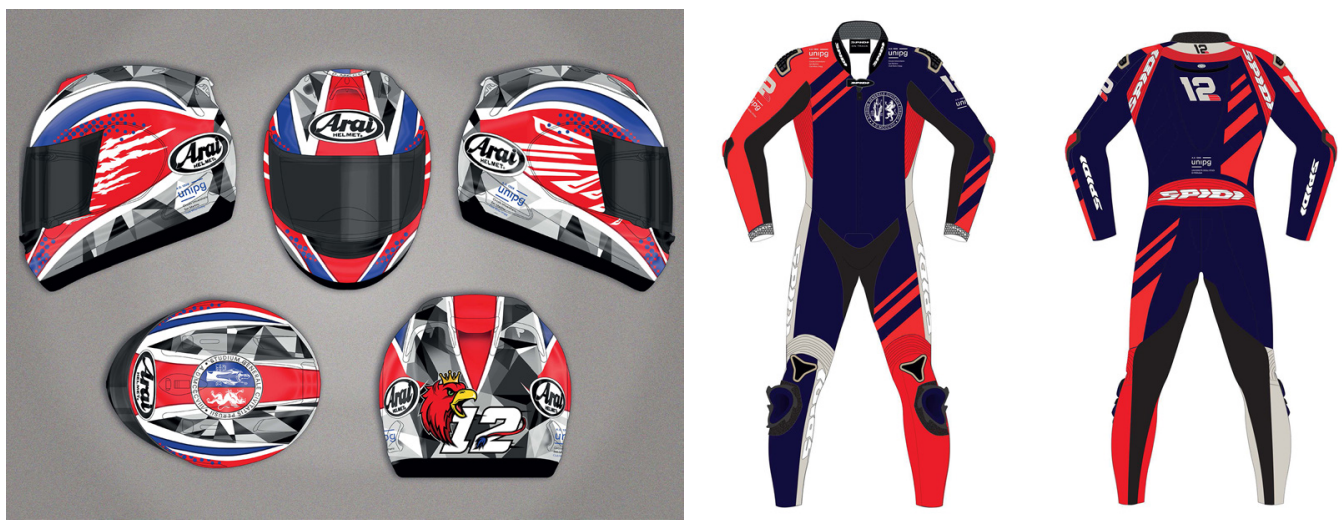

\section{Conclusions}

The impossibility of carrying out traditional laboratory activities, in which students and professors work side by side and confront each other directly and materially layering marks on the drawing sheet, in the three experiences presented was compensated for by the greater interactivity, the attenuation of interpersonal filters and the more intense collective participation, for the benefit of the entire class group and beyond the individual educational interests or the restricted group. The assiduity of student attendance and their active 
participation in lecture and review appointments indicated substantial effectiveness of the educational methods adopted, although the first workshop was initiated just three weeks into the lockdown. In this sense, the tools made available by the University and the prompt activation of the DL at the departmental level (in the case of the Department of Civil and Environmental Engineering, the start-up of telematic lessons followed the preventive suspension of teaching activities ordered at national level by just one week and the lockdown by only three days) have allowed activities to be carried out in a very effective manner. As the national health situation evolved, after the restoration of the possibility of travel between regions, students were able to participate in $\mathrm{DL}$ from their places of origin, both in other Italian regions and, occasionally, abroad. Broad participation showed minimal incidence of digital divide effects, with connections activated steadily from all locations. The positive balance of the three experiences encourages to permanently undertake an offer of drawing and Distance Learning, even after the end of the pandemic, as a form of support and integration of traditional modes of providing disciplinary activities and as a further possibility of remediation, always a harbinger of innovative experiences.

Fig. I I. Racing, neck warmer, winning project Ciprian Constantin Cazacu, Robert Paolo Requena Contreras, Ehsan Parikhi, Shahrad Shambayati).

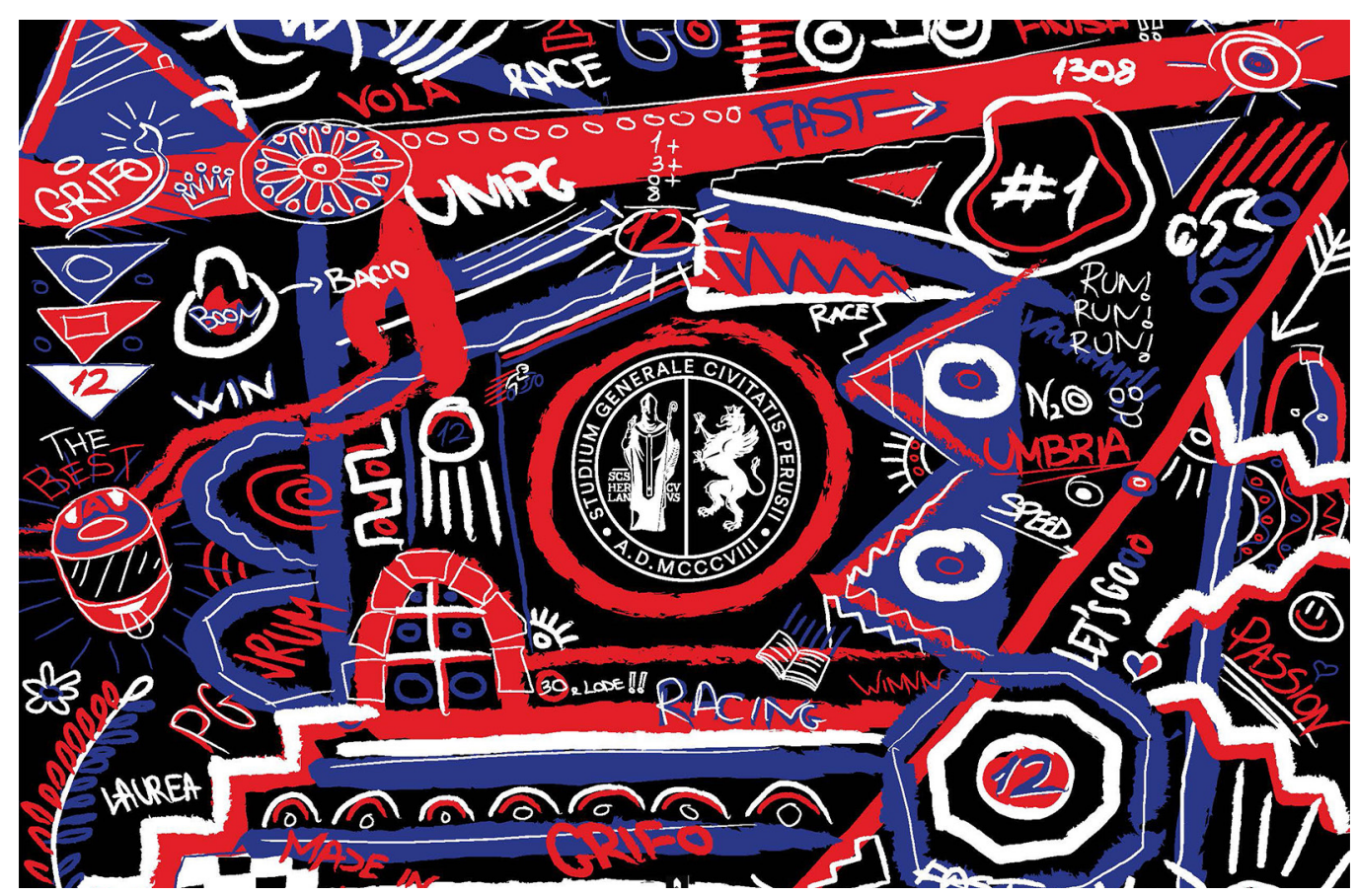

References

ANVUR (2020). Progetto "Didattica a Distanza - DaD": awviata la rilevazione online <https://www.anvurit/news/progetto-didattica-a-distanza-dad-avviata-la-rilevazione-online/> (accessed 2021, February 23).

Bollettino d'Ateneo (2020, July 28). Alto gradimento per la Dad di Unict, un sondaggio tra gli studenti premia l'impegno dell'Ateneo durante il lockdown <http://www.bollettino.unict.it/comunicati_stampa/alto-gradimento-la-dad-di-unict-un-sondaggio-tra-gli-studenti-premia-1\%E2\%80\%99impegno> (accessed 2021, February 23).

Bolter J.-D., Grusin R. (1999). Remediation. Understanding New Media. Cambridge, MA:The MIT Press.

Bruschi B., Perissinotto A. (2020). Didattica a distanza. Com'è, come potrebbe essere. Roma-Bari: Laterza.

Casetti F. (20I5). La galassia Lumière. Sette parole chiave per il cinema che viene. Milano: Saggi Bompiani.

De Paola M. (2020). Così il Covid-1 9 cambia l'università <https://www.lavoce.info/archives/670 I 8/cosi-il-covid-19-cambia-luniversita/> (accessed 2021, February 23). 
Della Monica M. P. (2021, February 10). Iniziare l'università ai tempi del Covid- 9 <https://www.asinupress.com/iniziare-luniversita-ai-tempi-del-covid-19/> (accessed on 202I February 23).

Giralucci S. (2021). Didattica a distanza. Intervista a Barbara Bruschi <https://fondazionezoe.it/2021/0I/26/intervista-a-barbara-bruschi/> (accessed 2021 , February 23)

Manzi A. (2017). Non è mai troppo tardi. Testamento di un maestro. Bologna: EDB, Centro editoriale dehoniano.

Martino S. (202I). Sondaggio Unimore: gli studenti amano la dad <https://www.ilrestodelcarlino.it/reggio-emilia/cronaca/sondaggio-unimore-gli-studenti-amano-la-dad-I.597| 698> (accessed 2021, February 23).

Pinotti A., Somaini A. (2016). Cultura visuale. Immagini sguardi media dispositivi. Torino: Einaudi.

Proietti G. (2020). Questionario Studenti UnivAQ sulla Didattica a Distanza. Analisi dei Risultati <https://mww.univaq.it/include/ utilities/blob.php?item=file\&table=allegato\&id=4695> (accessed 2021, February 23).

Ramella F., Rostan M. (2020). Gli accademici italiani e la didattica a distanza durante l'emergenza Covid- 19. Universi-DaD. <https://www.dcps.unito.it/do/documenti.pl/ShowFile?_id=gfk5;field=file;key=4G3PLidHy8YQAwy46cnWQSzYCxRhjocgmo6f2vGxXL03D8js7D6;t=3283> (accessed 2021, February 23).

Redazione Scuola (202I). Dad e università: i corsi di laurea accessibili da casa raccolti in un portale con le valutazioni di Anvur. <https://scuola24.ilsole24ore.com/art/universita-e-ricerca/202 I-02-03/dad-e-universita-corsi-laurea-accessibili-casa-raccolti-un-portale-le-valutazioni-anvur- 1 72040.php?uuid=ADi I gYHB> (accessed 202 I, February 23).

Sapienza Università di Roma (2020). Questionario di valutazione dell'esperienza con la didattica a distanza <https://web.uniroma I . it/disp/archivionotizie/questionario-di-valutazione-dellesperienza-con-la-didattica-distanza> (accessed 202I, February 23).

Strambi V. (2020). Firenze, il sondaggio: gli studenti universitari preferiscono la didattica a distanza <https://firenze.repubblica.it/ cronaca/2020/09/19/news/firenze_il_sondaggio_gli_studenti_universitari_preferiscono_la_didattica_a_distanza-2678 I 2204/> (accessed 2021, February 23).

Treleani M., Zucconi F. (2020). Editorial. In Img Journal, 2(3), 6-2 I. <https://doi.org/ l 0.6092/issn.2724-2463/I2243>(accessed 2021, February 23).

Tucci, C. (2021, February 18). L'affondo di Draghi: recuperare le ore perse. Verso le prove Invalsi da marzo <https://scuola24 ilsole24ore.com/art/scuola/202 I-02- I7/I-affondo-draghi-recuperare-ore-perse-le-prove-invalsi-marzo- | 8330 I.php?uuid=ADIRPbKB> (accessed 2021, February 23).

Università degli Studi di Catania (2020). Sondaggio per gli studenti sulla Didattica a Distanza <https://www.dfa.unict.it/it/notizie/ sondaggio-gli-studenti-sulla-didattica-distanza> (accessed 202I, February 23).

\section{Authors}

Paolo Belardi, Università di Perugia, paolo.belardi@unipg.it

Valeria Menchetelli, Università di Perugia, valeria.menchetelli@unipg.it

Giovanna Ramaccini, Università di Perugia, giovanna.ramaccini@unipg.it

To cite this chapter. Belardi Paolo, Menchetelli Valeria, Ramaccini Giovanna (2021). diDaD - diségno e Didattica a Distanza. Tre esperienze di rimediazione/diDaD - drawing and Distance Learning. Three remediation experiences. In Arena A., Arena M., Mediati D., Raffa P. (a cura di). Connettere. Un disegno per annodare e tessere. Linguaggi Distanze Tecnologie. Atti del $42^{\circ}$ Convegno Internazionale dei Docenti delle Discipline della Rappresentazione/Connecting. Drawing for weaving relationship. Languages Distances Technologies. Proceedings of the 42th International Conference of Representation Disciplines Teachers. Milano: FrancoAngeli, pp. I334- I 35 I. 